\title{
The response of microbial community in aerobic rice rhizosphere that affected by various plant growth stages and soil types
}

\author{
Nor Ayshah Alia Ali Hassan ${ }^{*}$, Radziah Othman² and Tosiah Sadi ${ }^{1}$ \\ ${ }^{1}$ Soil Science, Water, and Fertiliser Research Centre, Malaysian Agricultural Research and Development Institute, \\ Serdang, Selangor, Malaysia. \\ ${ }^{2}$ Institute of Tropical Agriculture and Food Security, Universiti Putra Malaysia, Serdang, Selangor, Malaysia. \\ Email: ayshalia@mardi.gov.my
}

\begin{abstract}
Aims: Aerobic rice is a potential crop introduced to encourage water conservation in rice planting. However, a decline of aerobic rice yield has been reported and thus this study was initiated with the aim to observe the response of microbial community in this environment which are exposed to various plant growth stage and soil types.

Methodology and results: To determine the effect of soil types such as peat and sandy clay loam on microbial community. A total of four growth stages were tested namely vegetative, reproductive, ripening and maturing. To determine the influence of growth stages and soil types towards microbial community in aerobic rice, Biolog Ecoplate ${ }^{\mathrm{TM}}$ technique was used to quantify the response of microbial community through microbial functional diversity and carbon source utilization. The abundance of culturable aerobic bacteria, fungi, actinomycetes, nitrogen-fixing microorganism and phosphate-solubilizing microorganism were determined using five different selective media. Soil physical and chemical properties as well as total nitrogen in plant tissues were also determined. It was found that microbial functional diversity during plant growth (except for microbial evenness) varied between the soil types. Correlation analysis revealed different relationships between carbon source utilization and microbial functional diversity in both soil types.

Conclusion, significance and impact of study: Microbial community in rhizosphere responded according to plant development which is primarily determined by soil type. Therefore, it is concluded that soil type particularly the soil physical and chemical properties are important factors in shaping the microbial community by directly influencing the rhizosphere environment.
\end{abstract}

Keywords: Microbial functional diversity, CLPP, MRIA 1, peat, sandy clay loam

\section{INTRODUCTION}

Aerobic rice was introduced to address the water scarcity problem and ultimately to promote water conservation in rice planting system. Principally, aerobic rice is the combination of trait taken from upland and high producing lowland rice varieties (Tuong and Bouman, 2003). Aerobic rice is grown in non-flooded fields with additional irrigation and high input (Bouman et al., 2007). The MRIA 1 aerobic rice variety was introduced by the Malaysian Agricultural Research and Development Institute in 2013 (Sariam et al., 2014).

The variety was produced through chemical mutation from IRRI parent variety (IR76569-259-1) with a potential yield of about $5 \mathrm{t} / \mathrm{ha}$. It has a short maturity period of 90 days. Although the yield is promising, reports on yield failures have also been observed in other aerobic rice varieties (George et al., 2002; Vermeulen, 2007). Among the factors identified in the yield decline of aerobic rice monoculture are abiotic and biotic stresses (Kreye et al., 2009). To increase the productivity of yield in aerobic rice, understanding the response of microbial community in this environment is essential.

As a biotic component, soil microorganism's interaction with ecosystem is imperative. It is well known that microbes are the main element of global biodiversity and they play a crucial role in the ecosystem functions such as nutrient cycling (Islam et al., 2017) as well as mitigation of greenhouse gases (Krishnan et al., 2017). The abundance and composition of microbial community are varying with different environment (Luo et al., 2016; Chang et al., 2017; Stagars et al., 2017). In agriculture, environmental factor influences soil microbes in a way that may affect crop yield and soil quality. For example, nitrogen-fixing microbes improve nitrogen availability which can benefit plant growth (Ahmadi-Rad et al., 2016). Other beneficial microbes like phosphate-solubilising bacteria have been reported to improve the soil soluble phosphate availability or phosphate concentration in plant tissues (Esmaeil et al., 2017).

Soil types were determined according to texture based on the percentage of sand, silt and clay. Therefore, soil physical and chemical properties are directly affected by 
soil types. Numerous works on the influence of soil types towards microbial community have already been done (Tkacz et al., 2015; Delgado-Baquerizo et al., 2016). To date, there is insufficient information on the microbial community in aerobic rice ecosystem, particularly on the effect of soil types. Furthermore, studies on microbes in the aerobic rice mostly emphasize on the use of beneficia microbes (Filippi et al., 2011) to control disease as well as for soil enrichment (Panhwar et al., 2013) and to improve grain yield ( $\mathrm{Li}$ et al., 2011). To address this issue, this study was conducted to understand the effect of growth stages (biotic factor) and soil types (abiotic factor) on the microbial community in the rhizosphere of aerobic rice. Biolog Ecoplate ${ }^{\mathrm{TM}}$ was used to evaluate the response of microbial community based on their physiological profile (Garland, 1997).

\section{MATERIALS AND METHODS}

\section{Experimental design}

This study was performed in the glasshouse at the Malaysian Agricultural Research and Development Institute. The aerobic rice variety seeds, MRIA 1 were planted in a planter box $(620 \mathrm{~mm} \times 230 \mathrm{~mm} \times 188 \mathrm{~mm})$. To determine the effect of soil type on microbial community, peat and sandy clay loam were used for planting. Peat was collected from non-cultivated land in Klang, Malaysia while sandy clay loam was collected near rubber plantation area in Serdang, Malaysia. There were 4 growth stages tested namely vegetative (tillering), reproductive (heading), ripening (milky grain) and maturing (fully developed grain). A total of 4 planter boxes used for each growth stage representing 4 replicates. In each planter box, 5 aerobic rice seeds were planted and composited as 1 replicate. The experiment was arranged in a randomized complete block design (RCBD).

Aerobic rice was grown according to standard manual developed by Sariam et al. (2015). Before planting, soil was thoroughly mixed using shovel, rack and trowel. Furrow with the depth of $5 \mathrm{~cm}$ were made to the soil. Aerobic rice seeds were soaked in tap water for $24 \mathrm{~h}$ to allow seed germination. Then, the seed were sown with the rate of $130 \mathrm{~kg} / \mathrm{ha}$ using the dry-direct seeding method and the seeds were covered with soil. The distance between each seed was $25 \mathrm{~cm}$. The soils were watered with the optimum water depth of $40 \mathrm{~mm}$ during the vegetative stage. The NPK compound fertilizer rate used for aerobic rice is $150: 60: 60 \mathrm{~kg} / \mathrm{ha}$ of $\mathrm{N}, \mathrm{P}_{2} \mathrm{O}_{5}$ and $\mathrm{K}_{2} \mathrm{O}$. The compound fertilizer was applied 5 days after sowing, 25 days after sowing and 45 days after sowing.

\section{Soil sampling}

Prior to planting, soil was collected at the depth of $20 \mathrm{~cm}$ using soil auger and considered as bulk soil. Rhizosphere soil was sampled at four different growth stages. Samples were collected 12 days after sowing (vegetative), 32 days after sowing (reproductive), 52 days after sowing (ripening) and 90 days after sowing (mature). The soil strongly adhered to the roots after gentle shaking was considered as rhizosphere soil.

\section{Soil physico-chemical properties}

Soil $\mathrm{pH}$ was measured by mixing soil sample in water at 1 : 2.5, soil: water ratio as according to standard method (Chapman and Pratt, 1978). Volumetric water content (VWC) was recorded using capacitance-type sensor by WatchDog 1000 Series Micro Stations (Spectrum Technologies Inc, USA) while soil salinity (EC) was measured using carbon ink electrodes by WaterScout SMEC 300 (Spectrum Technologies Inc, USA) at a soil depth between 0 and $20 \mathrm{~cm}$. Cation exchange capacity (CEC) and soluble phosphorus (SP) was performed using flow injection analyzer (Lachat Instruments, USA). Total carbon and total nitrogen were measured according to the combustion method by using elemental analyzer (Flash 2000, Thermo Scientific, USA).

\section{Determination of nitrogen in plant tissue}

Plant tissue samples were dried, ground, and weighed according to Campbell and Plank (1997). Nitrogen content in plant tissue was tested using the combustion method (Flash 2000, Thermo Scientific, USA).

\section{Microbial functional diversity analysis}

Microbial functional diversity was characterized by assessing the microbial activity and community level physiological profile. Biolog Ecoplate ${ }^{\mathrm{TM}}$ system was used to evaluate these two criteria. Ecoplate ${ }^{\mathrm{TM}}$ has 96 well with three replicates whereby each one comprises 31 functional carbon sources relevant to ecosystem. Microbial community responded to these carbon sources and thus give a pattern called metabolic fingerprints (Garland, 1997). Soil suspensions (soil $100 \mathrm{~g}$ and $1 \mathrm{~L}$ of distilled water) were shaken for $30 \mathrm{~min}$ and filtered using $0.45 \mu \mathrm{m}$ filter paper. Aliquots of $100 \mu \mathrm{L}$ were inoculated in the Ecoplate ${ }^{\mathrm{TM}}$ and incubated at $27^{\circ} \mathrm{C}$. The utilization of carbon source by microbes initiated the respiration in the cells and consequently reduces tetrazolium dye which produced the purple color. Colour intensity in each well was recorded as optical density (OD) at $590 \mathrm{~nm}$ wavelength. The OD was recorded at $48 \mathrm{~h}$ to permit microbial utilization of any soluble organic carbon derived from the rhizosphere that could hinder in the sole carbon source-use response (Gomez et al., 2004).

\section{Microbial activity}

Average well colour development was determined from OD values recorded at $590 \mathrm{~nm}$ wavelength produced after $48 \mathrm{~h}$ of Ecoplate ${ }^{\mathrm{TM}}$ incubation. Colour development in each well was evaluated after the plate incubation. Average well colour development (AWCD) was calculated as follows (Gomez et al., 2006): 
Malays. J. Microbiol. Vol 15(4) Special Issue 2019, pp. 277-288 DOI: http://dx.doi.org/10.21161/mjm.191543

$$
A W C D=\sum O D_{i} / 31
$$

where $O D_{i}$ is the optical density value from each Ecoplate $^{\mathrm{TM}}$ well.

\section{Community-level physiological profile}

Richness $(\mathrm{R})$, Shannon diversity Index $(\mathrm{H})$, and Shannon Evenness (E) were used as the criteria for communitylevel physiological profile (Garland, 1997). The values were calculated from the OD values of Ecoplate wells incubated at $48 \mathrm{~h}$. Richness was determined as the total number of oxidized carbon substrates (Biolog EcoPlate ${ }^{\mathrm{TM}}$ well with $O D \geq 0.25$ as threshold for positive response of oxidized carbon substrates). Shannon diversity Index was calculated as follows:

$$
H=\Sigma p i(\ln p i)
$$

where pi is the ratio of the activity on each substrate (ODi) to the sum of activities on all substrates ( $\Sigma O D i)$ in Biolog EcoPlate $^{\mathrm{TM}}$ well whereas $\mathrm{In}$ is the natural logarithm.

Shannon Evenness was analysed from the value of $\mathrm{H}$ and R (Zak, 1994) and calculated as follows:

$$
E=H / \ln R
$$

\section{Carbon source utilization}

Carbon source utilization was measured using the optical density in each Ecoplate well generated after $48 \mathrm{~h}$ incubation. A total of 31 substrates were categorized into 5 guilds (Weber and Legge, 2009).

\section{Enumeration of culturable aerobic microorganism}

Culturable aerobic microorganism was enumerated using the common total plate count. Total plate count was done on five different selective media which includes nutrient agar (NA), Burk's agar (NF), potato dextrose agar (PDA), Pikovskaya's agar (PS) and starch casein agar (SCA). Nutrient agar, NF, PDA, PS and SCA was used to quantify the abundance of bacteria, nitrogen-fixing microbes, fungi, phosphate-solubilizer and actinomycetes, respectively. Nutrient agar and PDA were made according to the manufacturer (Merck, Germany) recommendation. Burk's agar was made using $10 \mathrm{~g}$ glucose, $0.41 \mathrm{~g} \mathrm{KH}_{2} \mathrm{PO}_{4}, 0.52$ $\mathrm{g} \mathrm{K}_{2} \mathrm{HPO}_{4}, 0.05 \mathrm{~g} \mathrm{~K}_{2} \mathrm{HPO}_{4}, 0.05 \mathrm{~g} \mathrm{NaSO}_{4}, 0.2 \mathrm{~g} \mathrm{CaCl}_{2}$, $0.1 \mathrm{~g} \mathrm{MgSO}_{4} \cdot 7 \mathrm{H}_{2} \mathrm{O}, \quad 0.005 \mathrm{~g} \mathrm{FeSO}_{4} \cdot 7 \mathrm{H}_{2} \mathrm{O}, \quad 0.0025$ $\mathrm{Na}_{2} \mathrm{MoO}_{4} \cdot 2 \mathrm{H}_{2} \mathrm{O}, 15 \mathrm{~g}$ agar and $1 \mathrm{~L}$ of distilled water. Pikovskaya agar was consisted of $10 \mathrm{~g}$ glucose, $5 \mathrm{~g}$

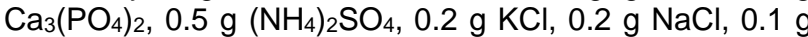
$\mathrm{MgSO}_{4}, 0.0001 \mathrm{~g} \mathrm{FeSO}_{4} \cdot 7 \mathrm{H} 2 \mathrm{O}, 0.0001 \mathrm{~g} \mathrm{MnSO}_{4}, 15 \mathrm{~g}$ of agar and $1 \mathrm{~L}$ of distilled water. SCA was made of $10 \mathrm{~g}$ soluble starch, $0.3 \mathrm{~g}$ casein, $2 \mathrm{~g} \mathrm{KNO}_{3}, 0.05 \mathrm{~g}$ $\mathrm{MgSO}_{4} \cdot 7 \mathrm{H}_{2} \mathrm{O}, 2 \mathrm{~g} \mathrm{~K}_{2} \mathrm{HPO}_{4}, 2 \mathrm{~g} \mathrm{NaCl}, 0.02 \mathrm{~g} \mathrm{CaCO}_{3}, 0.01$ g FeSO $4 \cdot 7 \mathrm{H}_{2} \mathrm{O}, 18 \mathrm{~g}$ of agar and $1 \mathrm{~L}$ of distilled water. Burk's agar, PS and SCA agar were adjusted to $7 \pm 0.2$ and autoclaved at $121{ }^{\circ} \mathrm{C}$ for $15 \mathrm{~min}$. Soil suspension was prepared by adding $10 \mathrm{~g}$ of soil into $90 \mathrm{~mL}$ of sterile distilled water and shake for $1 \mathrm{~h}$. A tenfold dilution series was performed on the soil suspension and aliquots of 1 $\mathrm{mL}$ were inoculated on selective media and incubated at $27{ }^{\circ} \mathrm{C}$ for $48 \mathrm{~h}$ for NA and PDA while NF, PS and SCA were incubated for $168 \mathrm{~h}$. Total plate count was measured using Colony Forming Unit (CFU) and expressed as $\log _{10}$ $\mathrm{CFU} / \mathrm{mL}$.

\section{Statistical analysis}

Pearson Coefficient Correlation was used to evaluate the relationship of the following: -

1. Between microbial functional diversity and soil physico-chemical properties

2. Between Ecoplate ${ }^{\mathrm{TM}}$ carbon source guild

Average well colour development, R, H, E and aerobic culturable microorganism were analyzed using ANOVA and multiple comparisons of means using Fisher's Least Significance Difference (LSD) test. Percentage of change was used to determine the amount of change in AWCD, $\mathrm{R}, \mathrm{H}, \mathrm{E}$ and aerobic culturable microorganism. All statistical analyses were performed with Minitab 17.

\section{RESULTS}

\section{Soil properties and plant total nitrogen}

In peat, the median of $\mathrm{pH}, \mathrm{EC}, \mathrm{VWC}, \mathrm{CEC}$, Total Carbon (TC), Soil Nitrogen (SN), carbon and nitrogen ratio $(\mathrm{C} / \mathrm{N})$, Soluble Phosphorus (SP) and Plant Total Nitrogen (PTN) were $5.82,0.035 \mathrm{mS} / \mathrm{cm}, 13.17 \%, 78.705 \mathrm{meq} / 100 \mathrm{gm}$, $32.32 \%, 1.65 \%, 15,46.05 \mathrm{ppm}$ and $1.41 \%$, respectively (Table 1). These data showed that the peat is moderately acidic, non-saline and less saturated soil. It has very high CEC, very high nitrogen content, have slow decomposition process and high level of soluble phosphorus. The median of sandy clay loam for $\mathrm{pH}, \mathrm{EC}$, VWC, CEC, TC, SN, C/N, SP and PTN were 4.84, 0.11 $\mathrm{mS} / \mathrm{cm}, 19.15 \%, 7.725 \mathrm{meq} / 100 \mathrm{gm}, 0.535 \%, 1.07 \%$, 16.6, $3.05 \mathrm{ppm}$ and $1.115 \%$, respectively (Table 1). These indicated that this soil is very strongly acid, non-saline and less saturated. It has low CEC, very high nitrogen content, have slow decomposition process and very low level of soluble phosphorus. 

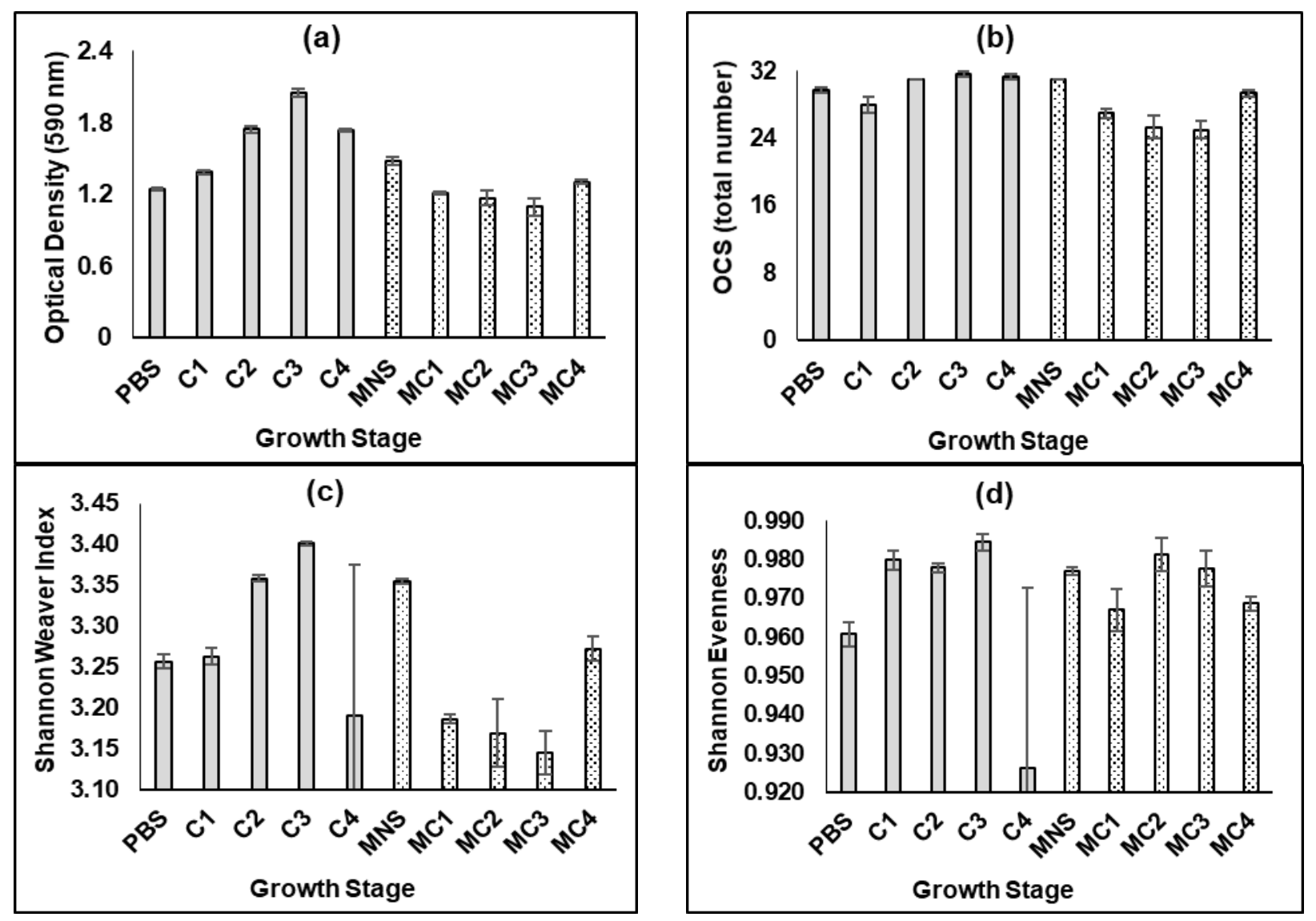

Figure 1: Mean separation of microbial functional diversity performed using Fisher's Least Significance Difference. [Mean with the same letter is not significant $(p \leq 0.05)$. (a) Microbial activity (b) Species richness (c) Catabolic diversity (d) Microbial evenness. PBS, Peat bulk soil; C1, Peat rhizosphere at vegetative stage; C2, Peat rhizosphere at reproductive stage; C3, Peat rhizosphere at ripening stage; C4, Peat rhizosphere at harvesting; MNS, Sandy clay loam soil; MC1, Sandy clay loam rhizosphere at vegetative stage; MC2, Sandy clay loam rhizosphere at reproductive; MC3, Sandy clay loam rhizosphere at ripening; MC4, Sandy clay loam rhizosphere at harvesting].
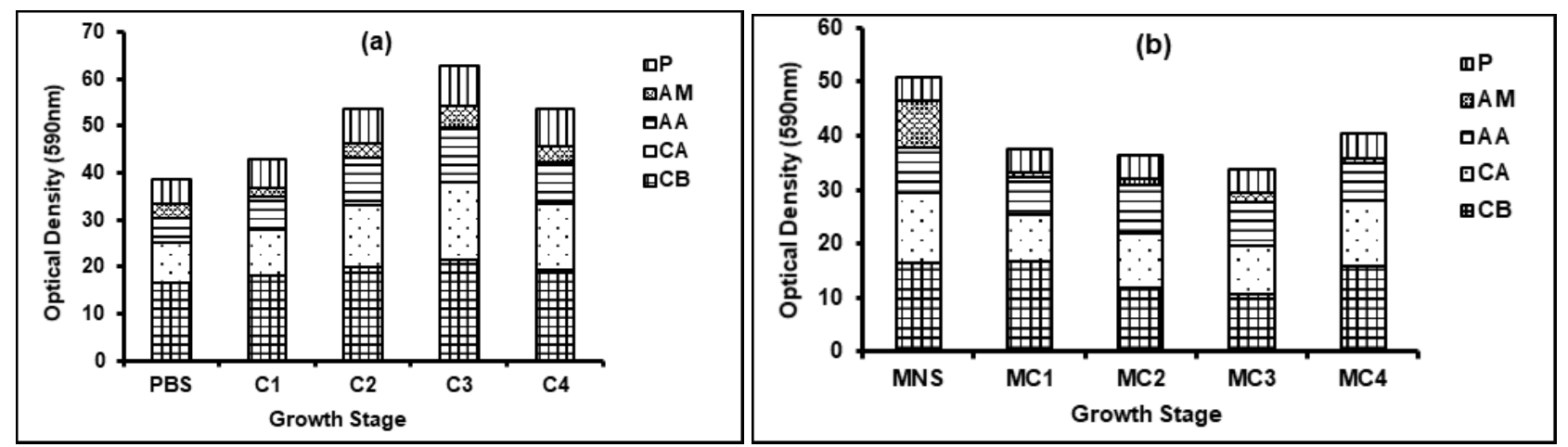

Figure 2: Carbon source utilization based on 5 guilds: (a) Carbon source utilization in peat soil. (b) Carbon source utilization in sandy clay loam. PBS, Peat bulk soil; C1, Peat rhizosphere during vegetative stage; C2, Peat rhizosphere during reproductive stage; C3, Peat rhizosphere during ripening stage; C4, Peat rhizosphere during harvesting; MNS, Sandy clay loam soil; MC1, Sandy clay loam rhizosphere during vegetative stage; MC2, Sandy clay loam rhizosphere during reproductive stage; MC3, Sandy clay loam rhizosphere during ripening stage; MC4, Sandy clay loam rhizosphere during harvesting; [P]: Polymer; [AM]: Amines and Amides; [AA]: Amino Acid; [CA]: Carboxylic and Acetic Acid; [CB]: Carbohydrates. 
Malays. J. Microbiol. Vol 15(4) Special Issue 2019, pp. 277-288 DOI: http://dx.doi.org/10.21161/mjm.191543

\section{Microbial activity}

Microbial activity was determined by measuring the ability of microorganisms to utilize the given substrate in Biolog Ecoplate. Hence, AWCD was used as indicator. In peat, the microbial activity in bulk soil was $38.8 \%$ lower compared to rhizosphere (Figure 1a). It is noted that there were $47.9 \%$ increase of microbial activity from vegetative stage until ripening stage in the rhizosphere. However, $15.1 \%$ decrease of microbial activity occurred towards the end of plant growth. On the contrary, microbial activity in the bulk soil of sandy clay loam was $23.8 \%$ higher than in rhizosphere. Meanwhile, there were no significant differences of microbial activity between all growth stages.

\section{Community-level physiological profile}

Figure $1 \mathrm{~b}$ showed that species richness in peat was $11.9 \%$ lower during vegetative stage as compared to other stages. However, there was no significant difference between species richness in reproductive, ripening and until harvesting stage. Whereas, there was no significant difference of species richness for rhizosphere in sandy clay loam whether for all growth stages or when compared with bulk soil.

Shannon Weaver Index was used to determine the microbial catabolic diversity. It was observed that $\mathrm{H}$ index and microbial evenness in rhizosphere of peat were not significantly different between the growth stages (Figure $1 \mathrm{c}$ and Figure 1d). The same scenario was detected between microorganisms, bulk soil and rhizosphere. Conversely, the bulk soil of sandy clay loam has $4.82 \%$ higher $\mathrm{H}$ index compared to rhizosphere. As for the rhizosphere, it was shown that a matured plant possesses highest $\mathrm{H}$ index among all growth stages. Figure 1d showed that growth stage did not affect the microbial evenness in sandy clay loam.

\section{Relationship between microbial functional diversity and soil properties}

The relationship between soil properties $(\mathrm{pH}$, soil salinity, $\mathrm{CEC}, \mathrm{C} / \mathrm{N}$ ratio, soluble phosphorus and plant total nitrogen) and microbial functional diversity were investigated. It was found that soil salinity has large negative association with species richness in the peat (Table 2a). On the other hand, in sandy clay loam it was shown that soil salinity has large negative association with microbial evenness (Table 2b).

\section{Carbon source utilization at different growth stages}

Carbon source utilization was categorized into 5 guilds. Overall, microbial community in the bulk soil of peat consumed $38.3 \%$ lower carbon source than microbial community in the rhizosphere (Figure 2a). It is noted that there was an increase in the consumption of carbon source from vegetative to ripening stage and followed by a decrease towards maturity. On the contrary, microbial community in the bulk soil of sandy clay loam consumed $26.9 \%$ higher carbon source than microbial community in the rhizosphere (Figure $2 \mathrm{~b}$ ). The utilization of carbon source was decreasing starting from vegetative to ripening stage followed by an increase of consumption towards the end of plant growth. Table 3 showed that several carbon sources were consumed by microbes from both soil types such as D-Malic acid, D-Galactonic Acid y-Lactone, LAsparagine, Putrescine and Tween 40.

For the peat, the microbial community consumption of carbohydrates has large positive association with carboxylic and acetic acid, amino acid as well as polymer (Table 4a). In addition, the utilization of carboxylic and acetic acid by the microbial community was positively correlated with amino acid and polymer. This positive association also found between amino acid and polymer. All carbon source guilds except for amides and amines have large positive association with microbial activity. It is also noted that species richness was positively correlated with amides and amines.

Different scenarios were observed with microbial community in sandy clay loam (Table 4b). Microbial activity has large positive association with the utilization of carboxylic and acetic acid as well as with species richness. Moreover, species richness was positively correlated with carboxylic and acetic acid. Meanwhile, Shannon diversity has large positive association with microbial activity and carboxylic and acetic acid. It was also observed that microbial evenness has large positive correlation with the consumption of amino acid.

\section{Population of culturable aerobic microorganism}

The enumeration of culturable aerobic microorganism was quantified using selective media. For bacterial abundance in peat rhizosphere, it was shown that reproductive stage has the lowest number of bacteria compared to other growth stages as well as when evaluating it with bulk soil (Table 5). In contrast, culturable bacterial abundance among growth stages in sandy clay loam as well as in their bulk soil was not significant. The highest fungi abundance in peat rhizosphere was during the vegetative stage of aerobic rice. Meanwhile, sandy clay loam does not harbour culturable fungi within stipulated incubation time. It was observed that growth stages of aerobic rice in both soil types did not have any significant differences on the abundance of actinomycetes that grown within fixed incubation time.

Growth stages did not influence the abundance of nitrogen-fixing microbes in the rhizosphere of peat because it did not have any significant differences. However, in sandy clay loam there was no nitrogen-fixing microbes detected during vegetative stages. In addition, the lowest nitrogen-fixing microbes were recorded in reproductive stages and the most abundance nitrogenfixing microbes were observed during ripening stage. Interestingly, there were no culturable phosphatesolubilizing microbes detected on bulk soil of both soil types. Culturable phosphate-solubilizing microbes were 
Malays. J. Microbiol. Vol 15(4) Special Issue 2019, pp. 277-288 DOI: http://dx.doi.org/10.21161/mjm.191543

observed in the rhizosphere of both soil types. However, the growth stage did not influence their abundances.

\section{DISCUSSION}

\section{Effect of growth stages on microbial community in peat}

The pattern of microbial activity in peat across all growth stages corresponded with the pattern of carbon source utilization for all guilds tested except for amides and amines. This indicates that there was a shift in microbial community at every growth stage to accommodate aerobic rice development. Quantitative composition of root exudates was influenced by plant development (Huang et al., 2014). Generally, root release exudates such as sugar, amino acid and organic acid. Therefore, microbial communities prefer to utilize those substrates first which explain the low usage of amides and amines in the peat. It was noted that microbial activity in bulk soil is lower than microbial activity in rhizosphere at vegetative stage of aerobic rice although the species richness results between bulk soil and vegetative stage were vice versa. In addition, microbial diversity and evenness in bulk and peat rhizosphere was not significantly different. Lower species richness during vegetative stage as compared to bulk soil could be attributed to high soil salinity recorded during this stage. Based on the correlation analysis, it was shown that soil salinity and species richness in peat was negatively correlated. We predicted that there was different microbial community composition in bulk soil. Chemical compound such as phytohormones was released during plant development and may alter the microbial community composition which narrowed down its species richness at first. Then, in order to serve its function, plant influence specific microbial community to proliferate and this increases the species richness that makes the microbial community uneven. This described why there was no effect of growth stages on microbial evenness and species diversity. These findings are in agreement with the previous studies (Luo et al., 2016, Zhang et al., 2015).

Carbon source preferred by microbial community during plant growth were carbohydrate, carboxylic and acetic acid, amino acid and polymer. Substrates such as D-mannitol and malic acid are present in rhizosphere and ready to be utilized by microbes. Microbes such as bacteria produced L-asparaginase enzyme (BadoeiDalfard, 2016) and thus amino acid L-asparagine is highly consumed by microbes. Aerobic rice also plays important role in carbon source preference where in this study microbial community highly utilized L-arginine. It is known that L-arginine is one of the main nitrogen storages formed in roots and act as crucial metabolite for plant development (Winter, 2015).

This study revealed that aerobic rice growth stages did not influence the abundance of culturable aerobic actinomycetes, nitrogen-fixing microorganism and phosphate-solubilizing microorganism. It was reported that high diversity of aerobic actinomycetes found in typical peat and agriculture-managed peat (Zenova et al., 2008). The sample collected for our study was rhizosphere and we had isolated free-living nitrogen-fixing microorganism. This study agrees with previous study (Tang et al., 2017) which hypothesized that the activity of free-living bacteria in rice fields was strongly correlated with soil nutrient status. In our study, peat with high nitrogen content and aerobic rice growth stages might not have directly influenced the culturable free-living nitrogen-fixing microorganisms.

\section{Effect of growth stages on microbial community in sandy clay loam}

As for the microbial community in sandy clay loam, our results demonstrated that there are large association between microbial activity with species richness and species diversity and all of these parameters have positive relationship with the utilization of carboxylic and acetic acid. Thus, it is predicted that microbial community in sandy clay loam is directly influenced by this carbon source. It was observed that microbial activity in bulk soil was higher than rhizosphere where microbial community in bulk soil utilized D-galacturonic acid most while in rhizosphere microbial community use other carbon source such as D-malic acid. D-galacturonic acid is an oxidized form of D-galactose that present in soil while D-malic acid is generally present in rhizosphere. Thus, there was a shift of microbial community where species richness and microbial diversity reduced in rhizosphere that ultimately lessens their microbial activity. As mentioned earlier, plant modifies microbial community in rhizosphere for plant growth.

Microbial activity, species richness and microbial evenness were not significant at every growth stage in sandy clay loam. In this study, D-malic acid was used by aerobic rice to recruit beneficial microbes for the advantage of plant growth. From our observation, this soil is strongly acidic and from previous work (Shamshuddin et al., 1992) it was saturated with aluminium. Aluminium toxicity can inhibit root growth especially in rice plant (Awasthi et al., 2017). Malic acid has been identified to be potential in aluminium detoxification (Jones et al., 1996). In order to counter aluminium toxicity, we predicted that the root of aerobic rice released malic acid. Since vegetative, reproductive and ripening stages are critical for plant development, microbial community is dominated with malic acid-utilizing microbes during this period. It was noted that microbial evenness has large negative association with the salinity of sandy clay loam tested. Since the salinity of the soil investigated was not consistent during aerobic rice growth, microbial community composition might also change according to this factor. These findings were not in agreement with previous study (Houlden et al., 2008) which showed rhizosphere community diversity in three different crops and the influence of plant growth stages on microbial community. Dissimilarity could happen because our soil was acidic while study from Houlden et al. (2008) was neutral ( $\mathrm{pH}$ 7.7). Moreover, our soil was sandy clay loam 
whereas in this prior study soil was classified as heavy clay. It was portrayed that the highest microbial diversity was in bulk soil and followed by mature growth stage. Microbial community in bulk soil and mature growth stage highly utilized D-galacturonic acid and D-galactonic acid, respectively. Both of these carbon sources are an oxidized form of d-galactose. Thus, it is suggested that as aerobic rice reached maturity, it starts to reduce production of the phytochemical needed for plant growth. Hence, rhizosphere environment was changed and became more similar to bulk soil condition. Microbial community composition in the rhizosphere was altered for adaptation in the new environment. Species that were dormant earlier when plant was growing were able to thrive in this new environment and increase the microbial community.

Table 1: Soil physico-chemical properties and plant total nitrogen.

\begin{tabular}{|c|c|c|c|c|c|c|c|c|c|c|}
\hline Soil type & $\begin{array}{l}\text { Growth } \\
\text { stage }\end{array}$ & $\mathrm{pH}$ & $\begin{array}{c}\mathrm{EC} \\
(\mathrm{mS} / \mathrm{cm})\end{array}$ & $\begin{array}{l}\text { VWC } \\
(\%)\end{array}$ & $\begin{array}{c}\text { CEC } \\
\text { (meq/100 gm) }\end{array}$ & $\begin{array}{l}\mathrm{TC} \\
(\%)\end{array}$ & $\begin{array}{l}\mathrm{SN} \\
(\%)\end{array}$ & $\mathrm{C} / \mathrm{N}$ & $\begin{array}{c}\mathrm{SP} \\
(\mathrm{ppm})\end{array}$ & $\begin{array}{l}\text { PTN } \\
(\%)\end{array}$ \\
\hline \multirow{4}{*}{ Peat } & Vegetative & 6.68 & 0.50 & 24.12 & 76.39 & 29.72 & 1.27 & 23 & 86.2 & nd \\
\hline & Reproductive & 7.44 & 0.18 & 23.63 & 90.95 & 61.03 & 3.98 & 15 & 62.8 & 3.00 \\
\hline & Ripening & 6.69 & 0.03 & 12.27 & 81.02 & 39.01 & 2.03 & 19 & 48.8 & 2.21 \\
\hline & Mature & 4.96 & 0.04 & 14.07 & 82.47 & 34.92 & 2.31 & 15 & 43.3 & 0.61 \\
\hline \multirow{4}{*}{$\begin{array}{l}\text { Sandy } \\
\text { Clay } \\
\text { Loam }\end{array}$} & Vegetative & 4.89 & 0.23 & 36.10 & 7.68 & 0.51 & 2.11 & 0.2 & 3.3 & nd \\
\hline & Reproductive & 5.04 & 0.09 & 27.83 & 8.01 & 0.56 & nd & nd & 13.2 & 2.04 \\
\hline & Ripening & 4.78 & 0.13 & 10.47 & 8.11 & 1 & 0.03 & 33 & 3.7 & 1.64 \\
\hline & Mature & 5.37 & 0.18 & 40.23 & 7.77 & 0.68 & nd & nd & 2.8 & 0.59 \\
\hline
\end{tabular}

EC, Electrical Conductivity; VWC, Volumetric Water Content; CEC, Cation Exchange Capacity; TC, Total Carbon; SN, Soil Total Nitrogen; C/N, Carbon/Nitrogen Ratio; SP, Soluble Phosphorus; PTN, Plant Total Nitrogen

${ }^{*}$ nd - not detected.

Table 2a: Coefficient Correlation using Pearson between selected soil properties and microbial functional diversity in peat.

\begin{tabular}{|c|c|c|c|c|c|c|c|c|c|c|}
\hline Variable & 1 & 2 & 3 & 4 & 5 & 6 & 7 & 8 & 9 & 10 \\
\hline \multicolumn{11}{|l|}{ 1. AWCD } \\
\hline 2. $\mathrm{R}$ & $\begin{array}{l}0.910 \\
0.090\end{array}$ & & & & & & & & & \\
\hline 3. $\mathrm{H}$ & $\begin{array}{l}0.576 \\
0.424\end{array}$ & $\begin{array}{l}0.309 \\
0.691\end{array}$ & & & & & & & & \\
\hline 4. $E$ & $\begin{array}{l}0.035 \\
0.965\end{array}$ & $\begin{array}{l}-0.290 \\
0.710\end{array}$ & $\begin{array}{l}0.821 \\
0.179\end{array}$ & & & & & & & \\
\hline 5. $\mathrm{pH}$ & $\begin{array}{l}-0.010 \\
0.990\end{array}$ & $\begin{array}{l}-0.196 \\
0.804\end{array}$ & $\begin{array}{l}0.792 \\
0.208\end{array}$ & $\begin{array}{l}0.912 \\
0.088\end{array}$ & & & & & & \\
\hline 6. EC & $\begin{array}{l}-0.896 \\
0.104\end{array}$ & $\begin{array}{c}-0.983 \\
0.017\end{array}$ & $\begin{array}{l}-0.189 \\
0.811\end{array}$ & $\begin{array}{l}0.399 \\
0.601\end{array}$ & $\begin{array}{l}0.357 \\
0.643\end{array}$ & & & & & \\
\hline 7. CEC & $\begin{array}{l}0.353 \\
0.647\end{array}$ & $\begin{array}{l}0.577 \\
0.423\end{array}$ & $\begin{array}{l}0.329 \\
0.671\end{array}$ & $\begin{array}{l}-0.021 \\
0.979\end{array}$ & $\begin{array}{l}0.348 \\
0.652\end{array}$ & $\begin{array}{c}-0.434 \\
0.566\end{array}$ & & & & \\
\hline 8. $\mathrm{C} / \mathrm{N}$ & $\begin{array}{l}-0.475 \\
0.525\end{array}$ & $\begin{array}{l}-0.790 \\
0.210\end{array}$ & $\begin{array}{l}0.065 \\
0.935\end{array}$ & $\begin{array}{l}0.543 \\
0.457\end{array}$ & $\begin{array}{l}0.239 \\
0.761\end{array}$ & $\begin{array}{l}0.742 \\
0.258\end{array}$ & $\begin{array}{l}-0.821 \\
0.179\end{array}$ & & & \\
\hline 9. SP & $\begin{array}{c}-0.820 \\
0.180\end{array}$ & $\begin{array}{l}-0.940 \\
0.060\end{array}$ & $\begin{array}{l}-0.021 \\
0.979\end{array}$ & $\begin{array}{l}0.542 \\
0.458\end{array}$ & $\begin{array}{l}0.514 \\
0.486\end{array}$ & $\begin{array}{l}0.985 \\
0.015\end{array}$ & $\begin{array}{l}-0.343 \\
0.657\end{array}$ & $\begin{array}{l}0.735 \\
0.265\end{array}$ & & \\
\hline 10. PTN & $\begin{array}{l}0.665 \\
0.335\end{array}$ & $\begin{array}{l}0.652 \\
0.348\end{array}$ & $\begin{array}{l}0.792 \\
0.208\end{array}$ & $\begin{array}{l}0.402 \\
0.598\end{array}$ & $\begin{array}{l}0.602 \\
0.398\end{array}$ & $\begin{array}{c}-0.504 \\
0.496\end{array}$ & $\begin{array}{l}0.824 \\
0.176\end{array}$ & $\begin{array}{c}-0.540 \\
0.460\end{array}$ & $\begin{array}{c}-0.353 \\
0.647\end{array}$ & \\
\hline
\end{tabular}

AWCD, Average Well Colour Development; R, Species Richness; H, Shannon Weaver Index; E, Microbial Evenness; EC, Electrical Conductivity; CEC, Cation Exchange Capacity; C/N, Carbon/Nitrogen Ratio; SP, Soluble Phosphorus; PTN, Plant Total Nitrogen Upper cell content is Pearson correlation while the lower cell content is P-value $(\leq 0.05)$. Cell with bold font indicates significant correlation. 
Table 2b: Coefficient Correlation using Pearson between selected soil properties and microbial functional diversity in sandy clay loam.

\begin{tabular}{|c|c|c|c|c|c|c|c|c|c|c|c|}
\hline Variable & 1 & 2 & 3 & 4 & & & 6 & 7 & 8 & 9 & 10 \\
\hline \multicolumn{12}{|l|}{ 1. AWCD } \\
\hline 2. $\mathrm{R}$ & $\begin{array}{l}0.956 \\
0.044\end{array}$ & & & & & & & & & & \\
\hline 3. $\mathrm{H}$ & $\begin{array}{l}0.960 \\
0.040\end{array}$ & $\begin{array}{l}0.976 \\
0.024\end{array}$ & & & & & & & & & \\
\hline 4. $E$ & $\begin{array}{l}-0.686 \\
0.314\end{array}$ & $\begin{array}{l}-0.789 \\
0.211\end{array}$ & $\begin{array}{l}-0.635 \\
0.365\end{array}$ & & & & & & & & \\
\hline 5. $\mathrm{pH}$ & $\begin{array}{l}0.888 \\
0.112\end{array}$ & $\begin{array}{l}0.829 \\
0.171\end{array}$ & $\begin{array}{l}0.929 \\
0.071\end{array}$ & $\begin{array}{l}-0.319 \\
0.681\end{array}$ & & & & & & & \\
\hline 6. EC & $\begin{array}{l}0.507 \\
0.493\end{array}$ & $\begin{array}{l}0.609 \\
0.391\end{array}$ & $\begin{array}{l}0.421 \\
0.579\end{array}$ & $\begin{array}{l}-0.967 \\
0.033\end{array}$ & & & & & & & \\
\hline 7. CEC & $\begin{array}{l}-0.791 \\
0.209\end{array}$ & $\begin{array}{l}-0.767 \\
0.233\end{array}$ & $\begin{array}{l}-0.646 \\
0.354\end{array}$ & $\begin{array}{l}0.907 \\
0.093\end{array}$ & & & $\begin{array}{l}-0.875 \\
0.125\end{array}$ & & & & \\
\hline 8. $\mathrm{C} / \mathrm{N}$ & $\begin{array}{l}-0.771 \\
0.229\end{array}$ & $\begin{array}{l}-0.561 \\
0.439\end{array}$ & $\begin{array}{l}-0.580 \\
0.420\end{array}$ & $\begin{array}{l}0.379 \\
0.621\end{array}$ & & 27 & $\begin{array}{l}-0.298 \\
0.702\end{array}$ & $\begin{array}{l}0.718 \\
0.282\end{array}$ & & & \\
\hline 9. SP & $\begin{array}{l}-0.257 \\
0.743\end{array}$ & $\begin{array}{l}-0.513 \\
0.487\end{array}$ & $\begin{array}{l}-0.362 \\
0.638\end{array}$ & $\begin{array}{l}0.774 \\
0.226\end{array}$ & & 819 & $\begin{array}{l}-0.761 \\
0.239\end{array}$ & $\begin{array}{l}0.437 \\
0.563\end{array}$ & $\begin{array}{l}-0.277 \\
0.723\end{array}$ & & \\
\hline 10. PTN & $\begin{array}{l}-0.614 \\
0.386\end{array}$ & $\begin{array}{l}-0.696 \\
0.304\end{array}$ & $\begin{array}{l}-0.524 \\
0.476\end{array}$ & $\begin{array}{l}0.985 \\
0.015\end{array}$ & & $\begin{array}{l}203 \\
97\end{array}$ & $\begin{array}{l}-0.991 \\
0.009\end{array}$ & $\begin{array}{l}0.926 \\
0.074\end{array}$ & $\begin{array}{l}0.403 \\
0.597\end{array}$ & $\begin{array}{l}0.720 \\
0.280\end{array}$ & \\
\hline \multicolumn{12}{|c|}{$\begin{array}{l}\text { AWCD, Average Well Colour Development; R, Species Richness; H, Shannon Weaver Index; E, Microbial Evenness; EC, Electrical } \\
\text { Conductivity; CEC, Cation Exchange Capacity; C/N, Carbon/Nitrogen Ratio; SP, Soluble Phosphorus; PTN, Plant Total Nitrogen } \\
\text { Upper cell content is Pearson correlation while the lower cell content is P-value }(\leq 0.05) \text {. Cell with bold font indicates significant } \\
\text { correlation. }\end{array}$} \\
\hline $\begin{array}{l}\text { Soil } \\
\text { Type }\end{array}$ & Growth stage & Carbo & ydrates & $\begin{array}{l}\text { Carboxy } \\
\text { acetic }\end{array}$ & & & ino acid & Amin & s \& amides & & Polymer \\
\hline \multirow{4}{*}{ Peat } & Vegetative & $\mathrm{D}-\mathrm{M}$ & innitol & D-Malic & & $\mathrm{L}-\mathrm{A}$ & paragine & & rescine & & Tween 40 \\
\hline & Reproductive & D-N & innitol & D-Malic & & L-A & sparagine & & rescine & & Tween 40 \\
\hline & Ripening & D-N & annitol & Itaconic & & & Arginine & & rescine & $\alpha-C$ & Cyclodextrin \\
\hline & Mature & D-N & annitol & $\begin{array}{l}\text { D-Galac } \\
\text { Acid } \gamma \text {-La }\end{array}$ & & L-A & paragine & Phen & ethylamine & $\alpha-C$ & Cyclodextrin \\
\hline \multirow{4}{*}{$\begin{array}{l}\text { Sandy } \\
\text { Clay } \\
\text { Loam }\end{array}$} & Vegetative & $\mathrm{D}-\mathrm{C} \epsilon$ & obiose & D-Malic & & L-A & paragine & & trescine & & Tween 40 \\
\hline & Reproductive & $\mathrm{D}-\mathrm{Ce}$ & lobiose & D-Malic & & & Serine & Phen & lethylamine & & Tween 40 \\
\hline & Ripening & $\begin{array}{l}\text { Pyru } \\
\text { Meth }\end{array}$ & $\begin{array}{l}\text { ic Acid } \\
\text { I Ester }\end{array}$ & D-Malic & & L-A & sparagine & & trescine & & Tween 40 \\
\hline & Mature & $\begin{array}{r}\text { b-Me } \\
\text { Glu }\end{array}$ & $\begin{array}{l}\text { thyl-D- } \\
\text { oside }\end{array}$ & $\begin{array}{l}\text { D-Galac } \\
\text { Acid } \gamma \text {-La }\end{array}$ & & & Serine & & trescine & & Tween 80 \\
\hline
\end{tabular}


Malays. J. Microbiol. Vol 15(4) Special Issue 2019, pp. 277-288

DOI: http://dx.doi.org/10.21161/mjm.191543

Table 4a: Coefficient Correlation using Pearson between carbon source guilds and microbial functional diversity in peat.

\begin{tabular}{|c|c|c|c|c|c|c|c|c|c|}
\hline Variable & 1 & 2 & 3 & 4 & 5 & 6 & 7 & 8 & 9 \\
\hline \multicolumn{10}{|l|}{ 1. CB } \\
\hline \multirow[t]{2}{*}{ 2. $\mathrm{CA}$} & 0.954 & & & & & & & & \\
\hline & 0.012 & & & & & & & & \\
\hline \multirow[t]{2}{*}{ 3. $A A$} & 0.996 & 0.946 & & & & & & & \\
\hline & 0.000 & 0.015 & & & & & & & \\
\hline \multirow[t]{2}{*}{ 4. AM } & 0.749 & 0.858 & 0.777 & & & & & & \\
\hline & 0.145 & 0.063 & 0.122 & & & & & & \\
\hline \multirow[t]{2}{*}{ 5. $P$} & 0.967 & 0.992 & 0.953 & 0.790 & & & & & \\
\hline & 0.007 & 0.001 & 0.012 & 0.112 & & & & & \\
\hline \multirow[t]{2}{*}{ 6. AWCD } & 0.980 & 0.992 & 0.979 & 0.849 & 0.987 & & & & \\
\hline & 0.003 & 0.001 & 0.004 & 0.069 & 0.002 & & & & \\
\hline \multirow[t]{2}{*}{ 7. $\mathrm{R}$} & 0.713 & 0.830 & 0.739 & 0.992 & 0.792 & 0.816 & & & \\
\hline & 0.176 & 0.082 & 0.154 & 0.026 & 0.110 & 0.092 & & & \\
\hline \multirow[t]{2}{*}{ 8. $\mathrm{H}$} & 0.642 & 0.487 & 0.688 & 0.554 & 0.453 & 0.577 & 0.351 & & \\
\hline & 0.243 & 0.405 & 0.199 & 0.333 & 0.444 & 0.308 & 0.563 & & \\
\hline \multirow[t]{2}{*}{ 9. E } & 0.236 & 0.004 & 0.267 & 0.009 & -0.007 & 0.105 & -0.250 & 0.819 & \\
\hline & 0.703 & 0.995 & 0.664 & 0.989 & 0.991 & 0.867 & 0.685 & 0.090 & \\
\hline
\end{tabular}

CB, Carbohydrate; CA, Carboxylic and acetic acid; AA, Amino acid; AM, Amides and amines; P, Polymer; AWCD, Average Well Colour Development; R, Species richness; $H$, Shannon Weaver Index; E, Microbial Evenness

Upper cell content is Pearson correlation while the lower cell content is P-value $(\leq 0.05)$. Cell with bold font indicates significant correlation.

Table 4b: Coefficient Correlation using Pearson between carbon source guilds and microbial functional diversity in sandy clay loam.

\begin{tabular}{|c|c|c|c|c|c|c|c|c|c|}
\hline Variable & 1 & 2 & 3 & 4 & 5 & 6 & 7 & 8 & 9 \\
\hline 1. CB & & & & & & & & & \\
\hline 2. CA & 0.506 & & & & & & & & \\
\hline 3. $A A$ & $\begin{array}{c}0.384 \\
-0.546\end{array}$ & 0.192 & & & & & & & \\
\hline 4. AM & $\begin{array}{l}0.341 \\
0.318\end{array}$ & $\begin{array}{l}0.757 \\
0.649\end{array}$ & 0.462 & & & & & & \\
\hline 5. $\mathrm{P}$ & $\begin{array}{c}0.602 \\
-0.071\end{array}$ & $\begin{array}{l}0.236 \\
0.289\end{array}$ & $\begin{array}{c}0.434 \\
-0.340\end{array}$ & -0.353 & & & & & \\
\hline 6. AWCD & $\begin{array}{l}0.910 \\
0.738\end{array}$ & $\begin{array}{l}0.638 \\
\mathbf{0 . 9 0 1}\end{array}$ & $\begin{array}{l}0.575 \\
0.077\end{array}$ & $\begin{array}{l}0.559 \\
0.792\end{array}$ & -0.055 & & & & \\
\hline 7. $\mathrm{R}$ & $\begin{array}{l}0.154 \\
0.798\end{array}$ & $\begin{array}{l}0.037 \\
0.899\end{array}$ & $\begin{array}{c}0.902 \\
-0.131\end{array}$ & $\begin{array}{l}0.110 \\
0.675\end{array}$ & $\begin{array}{l}0.930 \\
0.147\end{array}$ & 0.968 & & & \\
\hline 8. $\mathrm{H}$ & $\begin{array}{l}0.106 \\
0.693\end{array}$ & $\begin{array}{l}0.038 \\
0.943\end{array}$ & $\begin{array}{l}0.833 \\
0.060\end{array}$ & $\begin{array}{l}0.211 \\
0.770\end{array}$ & $\begin{array}{l}0.814 \\
0.090\end{array}$ & $\begin{array}{l}0.007 \\
0.998\end{array}$ & 0.982 & & \\
\hline 9. $E$ & $\begin{array}{c}0.194 \\
-0.716\end{array}$ & $\begin{array}{l}\mathbf{0 . 0 1 6} \\
0.003\end{array}$ & $\begin{array}{l}0.924 \\
\mathbf{0 . 9 7 4}\end{array}$ & $\begin{array}{l}0.127 \\
0.318\end{array}$ & $\begin{array}{c}0.886 \\
-0.301\end{array}$ & $\begin{array}{c}\mathbf{0 . 0 0 2} \\
-0.135\end{array}$ & $\begin{array}{c}\mathbf{0 . 0 0 3} \\
-0.327\end{array}$ & -0.141 & \\
\hline & 0.174 & 0.996 & 0.005 & 0.602 & 0.623 & 0.829 & 0.591 & 0.821 & \\
\hline
\end{tabular}

CB, Carbohydrate; CA, Carboxylic and acetic acid; AA, Amino acid; AM, Amides and amines; P, Polymer; AWCD, Average Well Colour Development; R, Species richness; $\mathrm{H}$, Shannon Weaver Index; E, Microbial Evenness.

Upper cell content is Pearson correlation while the lower cell content is P-value $(\leq 0.05)$. Cell with bold font indicates significant correlation. 
Malays. J. Microbiol. Vol 15(4) Special Issue 2019, pp. 277-288 DOI: http://dx.doi.org/10.21161/mjm.191543

Table 5: Population of culturable aerobic microorganism.

\begin{tabular}{|c|c|c|c|c|c|c|}
\hline $\begin{array}{l}\text { Soil } \\
\text { type }\end{array}$ & $\begin{array}{l}\text { Growth } \\
\text { stage }\end{array}$ & $\begin{array}{l}\text { Bacteria } \\
\left(\log _{10}\right. \\
\text { CFU/mL) }\end{array}$ & $\begin{array}{c}\text { Fungi } \\
\left(\log _{10}\right. \\
\text { CFU/mL) }\end{array}$ & $\begin{array}{c}\text { Actinomycetes } \\
\left(\log _{10}\right. \\
\text { CFU } / \mathrm{mL})\end{array}$ & $\begin{array}{l}\text { Nitrogen-fixing } \\
\text { microbes } \\
\text { (Log10 CFU/mL) }\end{array}$ & $\begin{array}{c}\text { Phosphate- } \\
\text { solubilizing } \\
\text { microbes } \\
\left(\log _{10} \mathrm{CFU} / \mathrm{mL}\right)\end{array}$ \\
\hline \multirow{5}{*}{ Peat } & Bulk soil & $8.25 \pm 0.01 a$ & $5.30 \pm 2.65 a b$ & $4.60 \pm 2.30 a$ & $6.85 \pm 0.03 a$ & $0.00 \pm 0.00 \mathrm{a}$ \\
\hline & Vegetative & $8.09 \pm 0.04 a$ & $7.40 \pm 0.10_{a}$ & $6.12 \pm 0.03 a$ & $5.91 \pm 0.14 a b$ & $3.65 \pm 1.83 a$ \\
\hline & Reproductive & $2.43 \pm 2.43 b$ & $0.00 \pm 0.00_{c}$ & $3.69 \pm 1.85 a$ & $3.57 \pm 1.79 b$ & $1.90 \pm 1.90 \mathrm{a}$ \\
\hline & Ripening & $7.20 \pm 0.20 a$ & $2.33 \pm 2.33 b c$ & $5.70 \pm 0.11_{a}$ & $6.17 \pm 0.01 \mathrm{a}$ & $3.75 \pm 1.88 \mathrm{a}$ \\
\hline & Mature & $8.02 \pm 0.06 a$ & $0.00 \pm 0.00_{c}$ & $6.35 \pm 0.03 a$ & $6.46 \pm 0.15 a$ & $0.00 \pm 0.00 \mathrm{a}$ \\
\hline \multirow{5}{*}{$\begin{array}{l}\text { Sandy } \\
\text { Clay } \\
\text { Loam }\end{array}$} & Bulk soil & $0.00 \pm 0.00_{A}$ & nd & $5.53 \pm 0.12 \mathrm{~A}$ & $5.75 \pm 0.03 B$ & $0.00 \pm 0.00_{A}$ \\
\hline & Vegetative & $0.00 \pm 0.00 \mathrm{~A}$ & nd & $3.43 \pm 1.72 \mathrm{~A}$ & $0.00 \pm 0.00 \mathrm{D}$ & $0.00 \pm 0.00_{A}$ \\
\hline & Reproductive & $2.63 \pm 2.63 \mathrm{~A}$ & nd & $3.43 \pm 1.72 \mathrm{~A}$ & $5.36 \pm 0.23 c$ & $3.69 \pm 1.85 \mathrm{~A}$ \\
\hline & Ripening & $4.87 \pm 2.44 \mathrm{~A}$ & nd & $5.10 \pm 0.10_{\mathrm{A}}$ & $6.81 \pm 0.10_{\mathrm{A}}$ & $1.87 \pm 1.87 \mathrm{~A}$ \\
\hline & Mature & $4.67 \pm 2.33_{A}$ & nd & $1.67 \pm 1.67_{\mathrm{A}}$ & $5.87 \pm 0.09_{B}$ & $0.00 \pm 0.00_{A}$ \\
\hline
\end{tabular}

Mean $\log _{10} \mathrm{CFU} / \mathrm{mL}$ measured based on different selective medium and data are expressed in means \pm SE. Mean comparison was performed using Fisher's Least Significance Difference. Mean in column with small letter is comparison in peat while mean in column with capital letter is comparison in sandy clay loam. Mean with the same letter is not significant $(p \leq 0.05)$.

*nd - no growth detected.

This study displayed that growth stages did not influence the abundance of culturable aerobic bacteria. As described earlier, species richness and microbial evenness in this sandy clay loam were stable throughout plant development and this might also happen with the abundance of aerobic bacteria. Interestingly, there were no culturable aerobic fungi detected in rhizosphere and bulk soil. Previous work showed the presence of arbuscular mycorrhizal fungi in Ultisol (Borie et al., 2010) and endophytic fungi in rice plant (Zakaria et al., 2010) where cultivation method and source of sample were different from our study. Our samples were taken from bulk soil and rhizosphere which may explain the lack of growth in the PDA. PDA used dextrose as main ingredient and mainly a glucose-based media. Based on result discussed earlier, microbial community in this soil showed high preference towards carboxylic and acetic acid which means culturable aerobic fungi might prefer organic acid rather than carbohydrates.

In sandy clay loam, the abundance of culturable aerobic actinomycetes was not significant in every aerobic rice growth stage as well as in bulk soil. In this study, our sandy clay loam is categorized as very strongly acidic and could decrease the growth of non-acidophilic actinomycetes. The $\mathrm{pH}$ of starch casein agar used to enumerate actinomycetes was 7 and acidophilic actinomycetes might not be able to grow well in this medium. In addition, this soil has low CEC and unable to retain more nutrient and might affect actinomycetes more than aerobic rice growth stages itself.

On the other hand, there was no culturable aerobic nitrogen-fixing microorganism during vegetative stage followed by an increase of abundance from reproductive to ripening stage. This indicates that aerobic rice growth stage affected the growth of culturable aerobic nitrogenfixing microorganisms. As mentioned before, growth stage did not affect species richness in sandy clay loam tested.
Therefore, only a few specific groups of microbes dominate this soil. When the root of aerobic rice elongated, it provides more possibility for symbiosis and enhanced the abundance of nitrogen-fixing microbes. This finding is concurred with prior study who found that the endosymbiosis between nitrogen-fixing rhizobium and legume root hairs had created the root nodule (Songkui et al., 2018).

\section{CONCLUSION}

To our knowledge, this study is the first to examine the influences of aerobic rice growth stages and soil types on microbial community composition. Results presented in this study provide evidence that the planting of aerobic rice have a major effect on determining the response and composition of microbial community in soil. Microbial community in rhizosphere responded according to plant effect produced during plant development which is primarily determined by soil type. Therefore, it is concluded that soil type particularly the soil physical and chemical properties are important factors in shaping the microbial community by directly influencing the environment of rhizosphere. This study majorly focuses on culturable microbes and quantification of non-culturable microbes need to be conducted in order to get a better understanding. Biolog Ecoplate ${ }^{\mathrm{TM}}$ still proves to be a critical approach in validating the response of microbial community and together with non-culturable analysis that may provide comprehensive information.

\section{ACKNOWLEDGEMENT}

The authors would like to thank Ministry of Agriculture and Agro-based Industry for providing the public funding (21003001480001) to conduct the study. 
Malays. J. Microbiol. Vol 15(4) Special Issue 2019, pp. 277-288 DOI: http://dx.doi.org/10.21161/mjm.191543

\section{REFERENCES}

Ahmadi-Rad, S., Gholamhoseini, M., Ghalavand, A., Asgharzadeh, A. and Dolatabadian, A. (2016). Foliar application of nitrogen fixing bacteria increases growth and yield of canola grown under different nitrogen regimes. Rhizosphere 2, 34-37.

Awasthi, J. P., Saha, B., Regon, P., Sahoo, S., Chowra, U., Pradhan, A., Roy, A. and Panda, S. A. (2017). Morpho-physiological analysis of tolerance to aluminum toxicity in rice varieties of North East India. PLOS ONE 12(4), e0176357.

Badoei-Dalfard, A. (2016). L-asparaginase production in the Pseudomonas pseudoalcaligenes strain JHS-71 isolated from Jooshan Hot-spring. Molecular Biology Research Communications 5(1), 1-10.

Borie, F., Rubio, R., Morales, A., Curaqueo, G. and Cornejo, P. (2010). Arbuscular mycorrhizae in agricultural and forest ecosystems in Chile. Journal of Soil Science and Plant Nutrition 10(3), 185-206.

Bouman, B. A. M., Humphreys, E., Truog, T. P. and Barker, R. (2007). Rice and water. Advances in Agronomy 92, 187-237.

Campbell, C. R. and Plank, C. O. (1997). Preparation of Plant Tissue for Laboratory Analysis. In: Handbook of Reference Methods for Plant Analysis. Kalra, Y. P. (ed.). CRC Press, Florida, United States. pp. 37-49.

Chang, E. H., Tian, G. and Chiu, C. Y. (2017). Soil microbial communities in natural and managed cloud Montane Forests. Forests 8(2), 1-9.

Chapman, H. D. and Pratt, P. F., (1978). Methods of analysis for soils, plants and waters. Oakland: University of California Division of Agriculture and Science. Priced Publication.

Delgado-Baquerizo, M., Grinyer, J., Reich, P. B. and Singh, B. K. (2016). Relative importance of soil properties and microbial community for soil functionality: insights from a microbial swap experiment. Functional Ecology 30, 1862-1873.

Esmaeil, B., Hemmatollah, P. and Khadijeh, S. L. (2017). Phosphate and potassium-solubilizing bacteria effect on the growth of rice. Ecological Engineering 103, 164-169.

Filippi, M. C. C., da Silva, G. B., Silva-Lobo, V. L., Côrtes, M. V. C. B., Moraes, A. J. G. and Prabhu, A. S. (2011). Leaf blast (Magnaporthe oryzae) suppression and growth promotion by rhizobacteria on aerobic rice in Brazil. Biological Control 58(2), 160166.

Garland, J. (1997). Analysis and interpretation of community-level physiological profiles in microbial ecology. FEMS Microbiology Ecology 24, 289-300.

George, T., Magbanua, R., Garrity, D. P., Tubana, B. S. and Quiton J. (2002). Rapid yield loss of rice cropped successively in aerobic soil. Agronomy Journal 94, 981-989.

Gomez, E., Ferreras, L. and Toresani, S. (2006). Soil bacterial functional diversity as influenced by organic amendment application. Bioresource Technology 97(13), 1484-1489.
Gomez, E., Garland, J. and Conti, M. (2004). Reproducibility in the response of soil bacterial community-level physiological profiles from a land use intensification gradient. Applied Soil Ecology 26(1), 2130.

Houlden, A., Timms-Wilson, T. M., Day, M. J. and Bailey, M. J. (2008). Influence of plant developmental stage on microbial community structure and activity in the rhizosphere of three field crops. FEMS Microbiology Ecology 65(2), 193-201.

Huang, X.F., Chaparro, J. M., Reardon, K. F., Zhang, R., Shen, Q. and Vivanco, J. M. (2014). Rhizosphere interactions: root exudates, microbes, and microbial communities. Botany 92, 267-275.

Islam, M. S., Zhang, Y., Dong, S., McPhedran, K. N., Rashed, E. M., El-Shafei, M. M., Noureldin, A. M. and Gamal El-Din, M. (2017). Dynamics of microbial community structure and nutrient removal from an innovative side-stream enhanced biological phosphorus removal process. Journal of Environmental Management 198(1), 300-307.

Jones, D. L., Prabowo, A. M. and Kochian, L. V. (1996). Aluminium-organic acid interactions in acid soils. Plant Soil 182(2), 229-237.

Kreye, C., Bouman, B. A. M., Reversat, G., Fernandez, L., Cruz, C. V., Elazegui, F., Faronilo, J. E. and Llorca, L. (2009). Biotic and abiotic causes of yield failure in tropical aerobic rice. Field Crops Research 112(1), 97-106.

Krishnan, Y., Bong, C. P. C., Azman, N. F., Zakaria, Z., Othman, N. A., Abdullah, N., Ho, C. S., Lee, C. T., Hansen, S. B. and Hara, H. (2017). Co-composting of palm empty fruit bunch and palm oil mill effluent: Microbial diversity and potential mitigation of greenhouse gas emission. Journal of Cleaner Production 146, 94-100.

Li, H., Ye, Z. H., Chan, W. F., Chen, X. W., Wu, F. Y., Wu, S. C. and Wong, M. H. (2011). Can arbuscular mycorrhizal fungi improve grain yield, as uptake and tolerance of rice grown under aerobic conditions? Environmental Pollution 159(10), 2537-2545.

Luo, X., Fu, X., Yang, Y., Cai, P., Peng, S., Chen, W. and Huang, Q. (2016). Microbial communities play important roles in modulating paddy soil fertility. Scientific Reports 6(20326), 1-12.

Panhwar, Q. A., Jusop, S., Naher, U. A., Othman, R. and Razi, M. I. (2013). Application of potential phosphate-solubilizing bacteria and organic acids on phosphate solubilization from phosphate rock in aerobic rice. The Science World Journal Article ID 272409. doi:10.1155/2013/272409.

Sariam, O., Azmi, M., Chan, C. S., Badrulhadza, A., Mohd, K. K. and Mohd, F. M. (2015). Manual Padi Aerob. Malaysia: Institut Penyelidikan dan Kemajuan Pertanian Malaysia.

Sariam, O., Zainudin, P. M. D. H., Chan, C. S., Azmi, M., Rosniyana, A. and Badrulhadza, A. (2014). Padi Aerob untuk mengatasi masalah kekurangan air. Jurnal Teknologi 70(6), 65-68. 
Shamshuddin, J., Jamilah, I., Sharifuddin, H. A. H. and Bell, L. C. (1992). Changes in solid phase properties of acid soils as affected by limestone, gypsum, palm oil mill effluent and rock phosphate applications. Pertanika Journal of Science and Technology 15(2), 105-114.

Songkui, C., Takuya, S., Rumi T. W. and Satoko, Y. (2018). Regulation and functional diversification of root hairs. Seminars in Cell and Developmental Biology 83, 115-122.

Stagars, M. H., Mishra, S., Treude, T., Amann, R. and Knittel, K. (2017). Microbial community response to simulated petroleum seepage in Caspian Sea sediments. Frontiers in Microbiology 8, 764.

Tang, Y. F., Zhang, M. M., Chen, A. L., Zhang, W. Z., Wei, W. X. and Sheng, R. (2017). Impact of fertilization regimes on diazotroph community compositions and $\mathrm{N}_{2}$-fixation activity in paddy soil. Agriculture, Ecosystems and Environment 247, 1-8.

Tkacz, A., Cheema, J., Chandra, G., Grant, A. and Poole, P. S. (2015). Stability and succession of the rhizosphere microbiota depends upon plant type and soil composition. ISME Journal 9(11), 2349-2359.

Tuong, T. P. and Bouman, B. A. M. (2003). Rice production in water-scarce environments. In: Water Productivity in Agriculture: Limits and Opportunities for Improvement. Kijne, J. W., Barker, R. and Molden D. (eds.). CABI Publishing, Wallingford, England. pp 5367.

Vermeulen, H. (2007). Evaluation of the aerobic rice technology: Three years of experiments in the Philippines. Internship Thesis, International Rice Research Institute.

Weber, K. P. and Legge, R. L. (2009). One-dimensional metric for tracking bacterial community divergence using sole carbon source utilization patterns. Journal of Microbiological Methods 79, 55-61.

Winter, G., Todd, C. D., Trovato, M., Forlani, G. and Funck, D. (2015). Physiological implications of arginine metabolism in plants. Frontiers in Plant Science 6(534), 1-14.

Zhang, X., Wang, X., Tang, Q., Li, N., Liu, P., Dong, Y., Pang, W., Yang, J. and Wang, Z. (2015). Effects of cultivation of OsrHSA transgenic rice on functional diversity of microbial communities in the soil rhizosphere. The Crop Journal 3, 163-167.

Zak, J. C., Willig, M. R., Moorhead, D. L. and Wildman, H. G. (1994). Functional diversity of microbial communities: A quantitative approach. Soil Biology and Biochemistry 26,1101-1108.

Zakaria, L., Yaakop, A. S., Salleh, B. and Zakaria M. (2010). Endophytic fungi from paddy. Tropical Life Sciences Research 21(1), 101-107.

Zenova, G. M., Gryadunova, A. A., Pozdnyakov, A. I. and Zvyagintsev, D. G. (2008). Aerobic and microaerophilic actinomycetes of typical agropeat and peat soils. Eurasian Soil Science 41(2), 210214. 